\title{
長母指伸筋腱皮下断裂に対し術後早期運動療法を行った 局所麻酔下腱移行術の検討
}

\author{
渡辺恵 理* 高㟝実* 畑中均*上條 秀 樹*
}

（目的）今回我々は，当院で長母指伸筋腱皮下断裂に対して局所麻酔下に固有示指伸筋腱の腱移行術を 行い，術後に早期運動療法を行った 5 例の成績について報告する。（方法）手術は，エピネフリン入り局 所麻酔下でターニケットを使用せずに施行した. 固有示指伸筋腱を長母指伸筋腱に 2 3 回 interlacing suture を行った後に，自動運動を行い，腱移行の緊張度を最終決定した。術後 1 週以内からセラピストの 監視下で自動可動域訓練を開始し，その後は屈曲制限付きの thumb spica splint を使用した。術後 4 週で ほぼ splint を除去した。(結果) 最終経過観察時の％TAM は，平均 $94.1 \%$ であった. Riddell の評価基準 では, excellent 4 例, good 1 例であり，良好な結果であった。（結論）長母指伸筋腱皮下断裂に対し，術 後早期運動療法を行った局所麻酔下腱移行術の成績は良好であった.

Key words:EPL Subcutaneous Rupture (長母指伸筋腱皮下断裂), therapeutic exercise in the early postoperative period (術後早期運動療法), tendon transfer under local anesthesia（局所麻 酔下腱移行術）

\section{緒 言}

長母指伸筋腱（以下 EPL 腱）断裂の皮下断裂に対 しては，固有示指伸筋腱（以下 EIP 腱）の腱移行術 が行われることも多く，良好な成績が報告されてい $る^{122) 32}$. しかし，母指指節間関節（以下 IP 関節）の可 動域制限をきたすこともあるため，腱移行術での腱縫 合による緊張度の決定や術後の後療法に関しては,さ まざまな報告がある年3，今回我々は，EPL腱皮下断 裂に対して，局所麻酔下に EIP 腱の腱移行術を行い, 術後に早期運動療法を行った 5 例についてその成績に ついて報告する。

\section{対象と方 法}

当院にて 2013 年 4 月から 2014 年 12 月までに手術 を施行した，5症例を対象とした。男性 2 例，女性 3 例であった。受傷時年齢は平均 65 歳（47〜80 歳）で あった。断裂の原因は，橈骨遠位端骨折が 4 例（手術 加療: 1 例, 保存 : 1 例, 受傷時未受診 : 2 例), 潜在 の橈骨遠位端骨折が疑われるものが 1 例（外傷のエピ ソードはあるが近医受診時にレントゲンでは骨折を認 めなかったもの）であった。

断裂は，全例で Lister 結節部での皮下断裂を認め た.手関節の外傷エピソードから断裂までの期間は, 受傷後が約 1 ケ月 : 3 例, 約 3 ケ月 : 1 例, 約 1 年 $: 1$
例であった。また，皮下断裂から手術までの期間は平 均 24 日（12 日〜39 日）であった。術後経過観察は最 低 3 ヶ月以上行った。

手術は，エピネフリン $1 \%$ 含有リドカインを皮切 部位に局所麻酔し, ターニケットは使用せずに行った。

EIP 腱を示指の MP 関節よりやや近位で切離し，近 位に反転した後に示指の総指伸筋腱の掌側を通した後 に, EPL 腱にEIP腱を $2 \sim 3$ 回 interlacing suture を 行った。術中に自動運動を患者本人に行わせ，腱移行 の緊張度を最終決定した。リハビリは，術後 2-3 日目 より，手関節 MP 関節伸展位で IP 関節のみの自動運 動を開始した。1 週間後より，IP 関節の屈曲を軽度ブ ロックしたLong thumb spica splint作成し, 装着し た。リハビリ時のみ，セラピスト監視下で splint を外 して自動可動域訓練を行わせた。ただこの際，IP 関 節・MP 関節・手関節の同時屈曲を禁じた。術後 3 週 から，IP関節制限なしの Short thumb spica へ変更 し, 自宅で splint を外しての自動可動域訓練を行わせ た. 術後 4 週で， splintを完全に off し， 6 週間後よ り，他動可動域訓練を行った。

術後評価は，母指 IP 関節と MP 関節の自動可動 域, \% TAM（総自動運動（total active motion）の健 側比), EPL 腱断裂術後の機能評価としては Riddell の評価基準 ${ }^{6)}$ を用いて評価を行った。

(母指\% TAM=患指(自動 IP 関節可動域＋自動 MP

* 独立行政法人労働者健康福祉機構九州労災病院整形外科 
表 1 術後最終観察時の可動域

\begin{tabular}{|c|c|c|c|c|c|c|}
\hline \multirow[b]{2}{*}{ 症例 } & \multirow[b]{2}{*}{ 年齢 } & \multirow[b]{2}{*}{ 性別 } & \multicolumn{3}{|c|}{ 母指（患側/健側） } & \multirow[b]{2}{*}{$\% \mathrm{TAM}$} \\
\hline & & & 患側 & $\operatorname{MP}\left({ }^{\circ}\right)$ & $\operatorname{IP}\left({ }^{\circ}\right)$ & \\
\hline (1) & 80 & 女 & 右 & $20 \sim 40 / 20 \sim 40$ & $20 \sim 60 / 20 \sim 70$ & 93.3 \\
\hline (2) & 47 & 女 & 左 & $10 \sim 50 / 10 \sim 55$ & $0 \sim 75 / 0 \sim 70$ & 100 \\
\hline (3) & 52 & 男 & 右 & $-20 \sim 40 / 0 \sim 40$ & $0 \sim 80 / 10 \sim 80$ & 76.9 \\
\hline (4) & 75 & 女 & 左 & $-10 \sim 60 /-10 \sim 60$ & $0 \sim 60 / 0 \sim 60$ & 100 \\
\hline (5) & 71 & 男 & 左 & $0 \sim 50 /-10 \sim 50$ & $0 \sim 70 / 10 \sim 70$ & 100 \\
\hline
\end{tabular}

平均 65

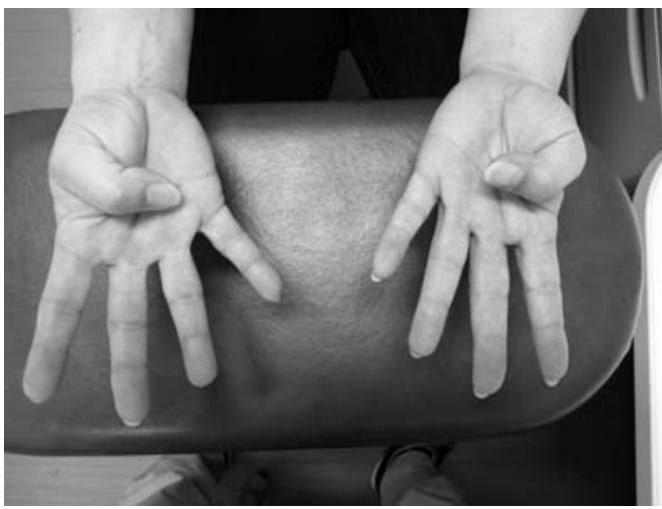

図 1 症例(1)

最終観察時（自動屈曲，左が患側）

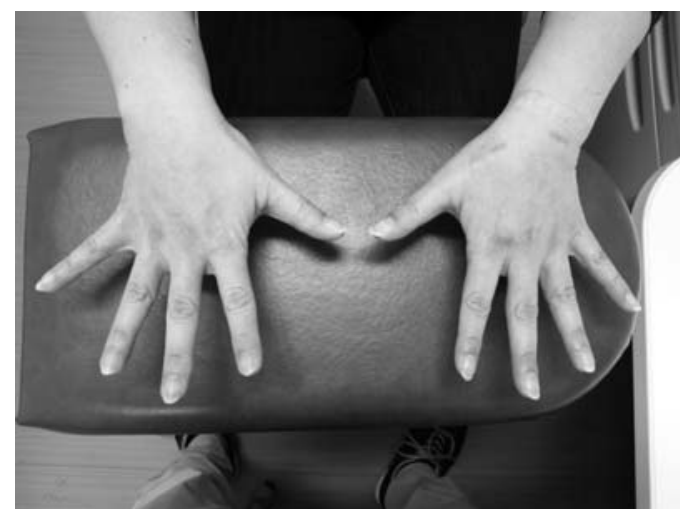

図 2 症例(1)

最終観察時（自動伸展，左が患側）
関節可動域)/健側指(自動 IP 関節可動域＋自動 MP 関節可動域 $) \times 100)$.

\section{結果}

術後平均経過観察期間は，平均 6.4 ケ月（ $3 \sim 11$ ケ月）であった。最終経過観察時の自動可動域は, MP 関節伸展平均 $0^{\circ}\left(-20 \sim 20^{\circ}\right)$, 屈曲平均 $48^{\circ}(40 \sim$ $\left.60^{\circ}\right)$, IP 関節伸展平均 $4^{\circ}\left(0 \sim 20^{\circ}\right)$, 屈曲平均 $69^{\circ}$ （60～80 ）であった％TAM（総自動運動（total active motion)) は, 平均 $94.1 \%(76.9 \sim 100 \%)$ であった.

Riddell の評価基準 ${ }^{6)}$ では, excellent 4 例, good 1 例であり，良好な結果であった。

\section{症 例 供 覧}

症例(1) 47 歳，女性。近医を受診したが，レントゲ ンで明らかな骨折は認めなかった。その後，疼痛は消
失したが，11 ケ月後に，左母指伸展不能となり当院 紹介受診となった. 左 EPL 腱皮下断裂と診断され, 腱 移行術を施行した。術後 6 ケ月では，自動可動域は $\mathrm{MP}$ 関節では伸展 $10^{\circ}$ 屈曲 $50^{\circ}$ (健側は伸展 $10^{\circ}$ 屈曲 $55^{\circ}$ ), IP 関節では伸展 $0^{\circ}$ 屈曲 $75^{\circ}$ (健側は伸展 $0^{\circ}$ 屈曲 $70^{\circ}$ ) であった（図 1，2）％ＴAM は，100\%で あった. Riddell の評価基準 ${ }^{6)}$ では, excellent であった. 症例(2) 52 歳，男性. 転倒し，右手をついて受傷し， 右手関節に腫脹と疼痛出現した。医療機関受診をしな かった。受傷 1 ケ月後に，重量物を持った際に，右母 指伸展不能となった。このため，当院を受診した。レ ントゲンで右橈骨遠位端骨折を認め，右 EPL 腱皮下 断裂を合併していると診断し, 腱移行術を施行した. この症例は, 術中腱移行後も母指の自動単独伸展がで きなかった（図 3，4）。最終経過観察時の自動可動域 は, MP 関節では伸展 $-20^{\circ}$ 屈曲 $40^{\circ}$ (健側は伸展 $0^{\circ}$ 


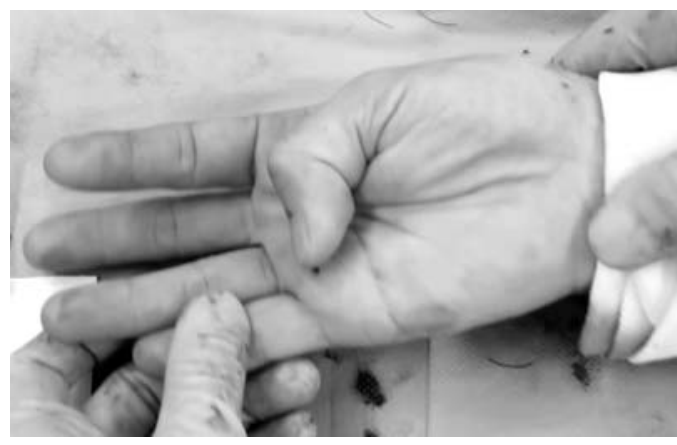

図 3 症例(2)

術中（腱移行後の自動屈曲）

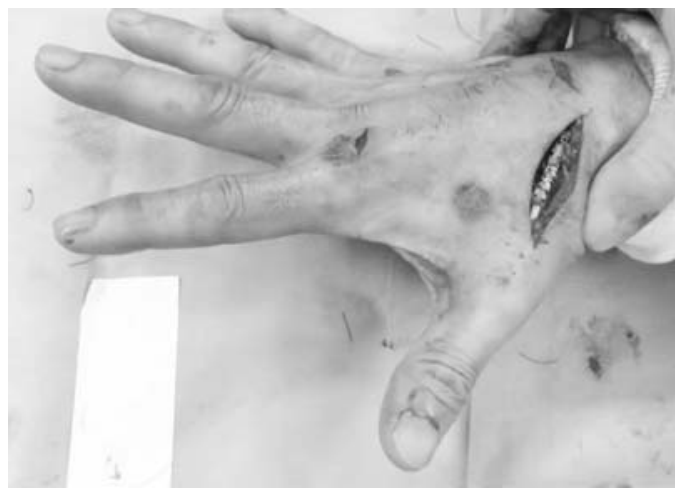

図 4 症例(2)

術中（腱移行後の自動伸展）

屈曲 $40^{\circ}$ ), IP 関節では伸展 $0^{\circ}$ 屈曲 $80^{\circ}$ (健側は伸展 $10^{\circ}$ 屈曲 $80^{\circ}$ ) であった（図 5，6）。\%TAM は 76.9\% で, Riddlleの評価基準 ${ }^{6)}$ で goodであった，可動域は MP 関節の伸展が若干悪かったが, 手の機能は良好で, 日常生活での機能障害の訴えはなかった.

\section{考察}

当院で手術を行った 5 例についての成績は, 全体と してはほぼ良好であった。また，局所麻酔下で手術を 行い, 手術中に腱の緊張を決定した先行論文との比較 では，西浦ら ${ }^{5)}$ や湯川ら とほぼ同等の成績であった。 たたし，1例のみやや不良例（症例(2)）を認めた。 この症例(2)では, 術中術後の母指伸展は十分であった が，最終経過観察時にはやや伸展不足（特にMP関 節）を生じた。この症例と他症例との相違点は，術中 腱移行後の自動運動で，母指の分離伸展運動が困難な

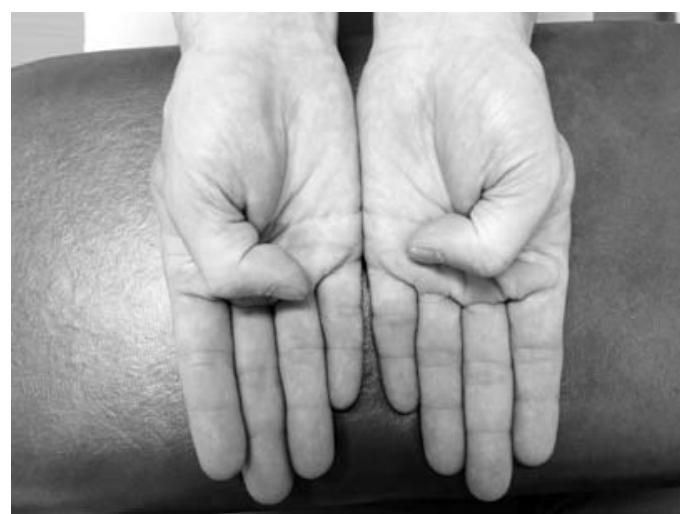

図 5 症例(2)

最終観察時（自動屈曲，右が患側）

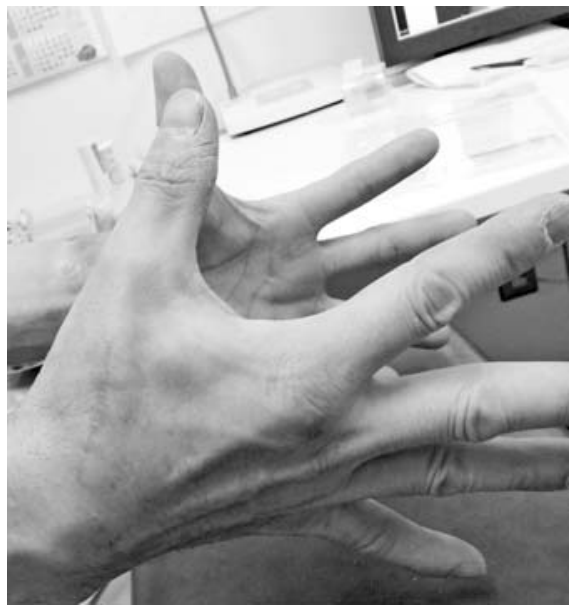

図 6 症例(2)

最終観察時（自動伸展，右が患側）

点であった。このため，術後もしばらくの間，母指と 示指の同時伸展運動でリハビリを行っていた，EPL 腱皮下断裂に対して, EIP 腱移行術が行われる理由は, $\mathrm{EIP}$ 腱の滑動距離が EPL 腱以上であることや, 走行 が類似している点があげられる ${ }^{344}$. しかし，さらに重 要な点は, 機能獲得のための再教育が必要ない点) で ある。森谷ら ${ }^{4)}$ は術中すぐに EIP 腱は, 示指伸展から 母指伸展への機能転換が完了することを報告してお り，当院での術中所見でもほとんどの患者で同様で あった。しかし症例(2)では術中の機能転換がうまく行 われなかったため，全指を伸展する方法で，完全伸展 できる緊張度であることを確認した。この点で，症例 
(2)は，他の症例とやや違った成績となったことが最も 考えられる，局所麻酔下での腱移行術は，術中に可動 域や，屈曲・伸展制限の可否を判断することができ， 確認後も調整可能な有用な方法である。また，早期運 動療法は, 術後の腱の癒着防止に有用であり, 当院で は，腱縫合を interlacing suture で行い，5例ではあ るが，最終観察時にもほぼ良好な可動域を得ている。 しかし, 術前・術中の示指伸展から母指伸展への機能 転換が良好でなければ，腱の癒着等による伸展不足が 生じる可能性があり，このことを考慮してリハビリ テーションを行う必要性があると思われた。

\section{結論}

長母指伸筋腱皮下断裂に対し，局所麻酔のみでの腱 移行術と, 術後早期運動療法を行った. 5 例中 1 例は good であったが，概ね，局所麻酔下腱移行術と早期 運動療法の成績は，諸家の報告同様に良好であった。 分離運動が不良な患者では, 術後のリハビリに注意を
要する必要があると思われた。

\section{引用 文 献}

1）文 浩光ら：橈骨遠位端骨折に続発した長母指伸筋腱 皮下断裂の治療経験. 中四整会誌，23(2)：333-336, 2011.

2）彦坂一雄ら：腱移行術における腱縫合時の緊張の決め 方一第 1 報 長母指伸筋腱について一. 日手会誌， 7 ： 603-666, 1990.

3）鬼頭宗久ら：腱緊張度を一定化した長母指伸筋腱断裂 再建術. 日手会誌，26：62-64, 2010.

4）森谷浩二ら：母指機能再建に抒ける固有示指伸筋. 整・災外, 55: 81-85, 2012.

5）西浦康正ら：局所麻酔下に手術を行い術後早期運動療 法を行った長母指伸筋腱断裂に対する腱移行術. 日手会 誌, 27(5)：607-609, 2011.

6) Riddell, D. M., et al.: Spontaneous rupture of the extensor pollicis longus : The result of tendon transfer. J. Bone Joint Sung., 45 B : 506-510, 1963.

7）湯川昌広ら：長母指伸筋腱皮下断裂に対する固有示指 伸筋腱移行術一局所麻酔下自動運動による腱緊張度の決 定法と他方との比較. 日手会誌, 30(4)：539-541, 2014. 